\title{
Update of the Gene Discovery Program in Schistosoma mansoni with the Expressed Sequence Tag Approach
}

\author{
Élida ML Rabelo, Glória R Franco*, Vasco AC Azevedo**, Heloisa B Pena*, \\ Túlio M Santos*, Wendell SF Meira*, Neuza A Rodrigues*, José Miguel Ortega*, \\ Sérgio DJ Pena*/+
}

Departamento de Parasitologia *Departamento de Bioquímica e Imunologia **Departamento de Biologia Geral, ICB, Universidade Federal de Minas Gerais, Av. Antônio Carlos 6627, 31270-901 Belo Horizonte, MG, Brasil

Continuing the Schistosoma mansoni Genome Project 363 new templates were sequenced generating 205 more ESTs corresponding to 91 genes. Seventy four of these genes (81\%) had not previously been described in S. mansoni. Among the newly discovered genes there are several of significant biological interest such as synaptophysin, NIFs-like and rho-GDP dissociation inhibitor.

Key words: Schistosoma mansoni - genome project - expressed sequence tags

The study of the Schistosoma mansoni genome has a high priority in the effort to understand the multiple facets of this complex parasite. Accordingly, a $S$. mansoni genome project was started in 1992 as a Brazilian initiative. From the original cDNA library used, 607 ESTs were generated (Franco et al. 1995a,b) leading to the identification of 154 new genes. This increased considerably the number of known genes in S. mansoni.

The $S$. mansoni genome project was adopted by the World Health Organization (WHO) and has been partially funded by this institution in a collaborative international project with the aim of undertaking a co-ordinated gene discovery program in S. mansoni. We wish to report the sequencing of 363 further templates by our laboratory, with identification of 91 genes, 74 of which have not been previously described in S. mansoni.

\section{MATERIALS AND METHODS}

Plasmidial DNA preparation, sequencing and analysis of the sequences were done essentially as described by Franco et al. (1995a).

\section{RESULTS}

Tables I an II summarise the data found in the 363 templates sequenced, which produced 205 useful ESTs derived from 185 clones. Some clones were sequenced in both directions using the forward and reverse primers and thus producing two ESTs for the same gene. That is the reason why there are 205

This investigation received financial support from the following institutions: UNDP/WORLD BANK/WHO Special Programme for Research in Tropical Diseases (TDR) (ID no. 940325, 940751); FAPEMIG Process no. CBS 1190/95; CNPq and PADCT.

${ }^{+}$Corresponding author. Fax: +55-31-441.5409

Received 16 April 1997

Accepted 30 June 1997
ESTs for 185 clones. All sequences were submitted to homology searches in DNA and protein databanks showing that the 205 ESTs corresponded to 91 different genes, $81 \%$ of which had not been previously described in the parasite. The sequences were grouped according to the following criteria: sequences presenting homology to previous identified S. mansoni genes (Tables II and III), sequences identified by homology with other organisms (Tables II and IV) and sequences with no homology with any gene deposited in database banks (Table II). Sequences showing low homology with other organisms were identified as partial matches (Tables II and V).

\section{TABLE I}

Information about sequencing of the Schistosoma mansoni cDNA library

\begin{tabular}{lc}
\hline Number of sequenced templates & 363 \\
Number of ESTs & 205 \\
Number of clones & 185 \\
Number of different genes & 91 \\
Average EST size & $372 \mathrm{nt}$ \\
Average polyA tail length & $23 \mathrm{nt}$ \\
\hline
\end{tabular}

TABLE II

EST categories of Sm cDNA library

No. of clones $(\%)$

\begin{tabular}{lcc}
\hline Putatively identified & & \\
$\quad$ Sm match & 47 & 22.7 \\
$\quad$ Non Sm match & 62 & 35.7 \\
Not identified & & \\
$\quad$ Non Sm partial match & 4 & 2.2 \\
$\quad$ Non database match & 57 & 31.3 \\
Mitochondrial & 0 & 0 \\
rRNA & 12 & 6.5 \\
Vector without insert & 3 & 1.6 \\
\hline Total & 185 & 100.0 \\
\hline
\end{tabular}


TABLE III

Characterization of ESTs: database match of ESTs to Sm genes

\begin{tabular}{|c|c|c|c|c|c|c|c|c|}
\hline EST name & $\begin{array}{l}\text { dbEST } \\
\text { Acces }\end{array}$ & Homology with (accession) & $\begin{array}{l}\text { Identity } \\
(\%)\end{array}$ & $\begin{array}{l}\text { Length } \\
\text { (nt) }\end{array}$ & $\begin{array}{l}\text { Number } \\
\text { of clones }\end{array}$ & Program & Score & Probability \\
\hline SMPBE13F & W06737 & alpha-tubulin (GB:S98950) & 98.5 & 274 & 3 & FASTA & 1068 & \\
\hline SMPBD26F & W06720 & Calreticulin (GB:SCMCALRET) & 98.3 & 460 & 1 & BLASTN & 2230 & $5.7 \mathrm{e}-183$ \\
\hline SMPBE11F & W06736 & Fructose 1,6 bisphosphate aldolase (GP:SCMALDO_1) & 98.0 & 432 & 7 & FASTA & 1156 & \\
\hline SMPBG05F & W06784 & GAPDH (GB:SCMGAPDH) & 99.6 & 252 & 11 & FASTA & 989 & \\
\hline SMPBE62Fwazzu & W06751 & GST (GB:SCMANT28K) & 98.6 & 291 & 9 & FASTA & 1148 & \\
\hline SMPBF02F & W06765 & HSP 86 (GB:SCMHSP86) & 99.0 & 387 & 1 & FASTA & 1532 & \\
\hline SMPBG92F & W06807 & Myosin heavy chain (GB:SCMMYH) & 99.6 & 262 & 2 & BLASTN & 1301 & $1.2 \mathrm{e}-100$ \\
\hline SMPBF01F & W06764 & ER -luminal cysteine protease ER 60 gene (GB:SMF1PSPCX) & 97.9 & 380 & 1 & BLASTN & 1830 & $9.9 \mathrm{e}-145$ \\
\hline SMPBE24F & W06741 & Sm750 gene (GB:SCMSM750) & 96.2 & 240 & 2 & FASTA & 902 & \\
\hline SMPBE51F & W06747 & Triose phosphate isomerase (GB:SCMSGTPI05) & 100.0 & 256 & 2 & BLASTN & 1280 & 1.6e-101 \\
\hline SMPBE92F & W06761 & Tropomyosin (GB:SCMTROPO) & 99.7 & 369 & 2 & BLASTN & 1836 & $1.2 \mathrm{e}-145$ \\
\hline SMPBE03F & W06734 & Actin (GB: M80334) & 96.6 & 304 & 14 & BLASTN & 1138 & $3.4 \mathrm{e}-87$ \\
\hline SMPBF30F & W06772 & Fibrillin 2 mRNA & 89.2 & 337 & 1 & BLASTN & 673 & $1.7 \mathrm{e}-99$ \\
\hline SMPBG29F & W06788 & Elongation factor 1-alpha (EMB:SMF1ALPH) & 97.5 & 405 & 3 & BLASTN & 1902 & $5.5 \mathrm{e}-151$ \\
\hline SMPBD40R & W06733 & Y-box binding protein (GB: U398831) & 97.8 & 358 & 10 & BLASTN & 1536 & $4.9 \mathrm{e}-125$ \\
\hline SMPBE59F & W06749 & BBC-1 (GB:U57003) & 98.9 & 373 & 2 & BLASTN & 1400 & $6.8 \mathrm{e}-147$ \\
\hline SMPBG90F & W06805 & Tropomyosin (GB:SCMTPM) & 100.0 & 200 & 1 & BLASTN & 1000 & $9.0 \mathrm{e}-76$ \\
\hline
\end{tabular}


TABLE IV

Characterization of ESTs: database match of EST to non-Sm genes

\begin{tabular}{|c|c|c|c|c|c|c|c|c|c|}
\hline EST name & $\mathrm{dbEST}$ & Homology with (accession) & $\begin{array}{l}\text { Similary } \\
(\%)\end{array}$ & $\begin{array}{c}\text { Identity } \\
(\%)\end{array}$ & $\begin{array}{c}\text { Length } \\
\text { (aa) }\end{array}$ & $\begin{array}{l}\text { Number } \\
\text { of clones }\end{array}$ & Program & Score & Probability \\
\hline SMPBF59F & W06782 & Aldose reductase(PDB:1DLA) & 72.5 & 53.8 & 80 & 1 & BLASTX & 219 & $1.4 \mathrm{e}-23$ \\
\hline SMPBF07F & W06768 & Asp-tRNA synthetase (SP:SYD_CAEEL) & 85.8 & 74.2 & 155 & 1 & BLASTX & 625 & $1.0 \mathrm{e}-80$ \\
\hline SMPBE38F & W06746 & C. elegans clone C16C10.10 (GP:CEC16C10_4) & 75.0 & 57.4 & 68 & 1 & BLASTX & 210 & $2.3 e-22$ \\
\hline SMPBG74F & W06795 & Dihydrolipoamide Acetyltransferase (GP:RATPDCE2_1) & 83.3 & 72.9 & 48 & 2 & BLASTX & 192 & $5.1 \mathrm{e}-39$ \\
\hline SMPBD30R & W06722 & DNAJ homolog (PIR:S42031) & 79.2 & 69.8 & 53 & 2 & BLASTX & 194 & $4.1 \mathrm{e}-38$ \\
\hline SMPBE17F & W06739 & Enolase (SP:ENO_SCHJA) & 95.9 & 87.6 & 73 & 2 & BLASTX & 348 & $1.6 \mathrm{e}-41$ \\
\hline SMPBE97R & W06821 & Glutamine Synthetase (SP:GLNA_HUMAN) & 78.6 & 66.0 & 103 & 1 & BLASTX & 413 & $5.0 \mathrm{e}-51$ \\
\hline SMPBG67F & W06794 & H+-transporting ATP synthase alpha-chain (PIR:S14516) & 6) 80.2 & 64.8 & 91 & 1 & BLASTX & 303 & $3.3 e-37$ \\
\hline SMPBD33R & W06725 & Homo sapiens 9G8 splicing factor (GP:HUM9G8SF_1) & 70.7 & 63.8 & 58 & 2 & BLASTX & 184 & $4.9 e-37$ \\
\hline SMPBE61F & W06750 & Human Alu subfamily (SP:ALU7_HUMAN) & 76.7 & 67.4 & 43 & 1 & BLASTX & 154 & $1.2 \mathrm{e}-14$ \\
\hline SMPBF15F & W06771 & Hypothetical protein 5 Xanthobacter sp (PIR:S47055) & 60.0 & 44.0 & 125 & 1 & BLASTX & 271 & $2.6 \mathrm{e}-31$ \\
\hline SMPBE28F & W06744 & Lactate dehydrogenase (GP:MUSLDHB_1) & 75.4 & 45.9 & 61 & 3 & BLASTX & 158 & $1.8 \mathrm{e}-15$ \\
\hline SMPBE82F & W06757 & NIFS-like 54.5KD protein (SP:NFS1_YEAST) & 65.6 & 53.6 & 125 & 1 & BLASTX & 328 & $1.2 \mathrm{e}-38$ \\
\hline SMPBE27F & W06743 & Phosphoglycerate mutase (SP:PMG1_ECOLI) & 177.6 & 67.2 & 67 & 1 & BLASTX & 239 & $1.3 e-26$ \\
\hline SMPBD34R & W06727 & Polyadenylate binding protein (DBJ:HUMPOLYABP) & 76.3 & 74.8 & 127 & 1 & BLASTX & 400 & $2.3 e-23$ \\
\hline SMPBD23F & W06714 & Purine nucleoside phosphorylase (PDB:1ULA) & 35.5 & 55.5 & 45 & 2 & BLASTX & 76 & $2.9 \mathrm{e}-15$ \\
\hline SMPBF65F & W06783 & Ribosomal protein L5 (SP:RL5A_XENLA) & 73.4 & 52.1 & 94 & 3 & BLASTX & 252 & $5.0 \mathrm{e}-28$ \\
\hline SMPBH15F & W06814 & Ribosomal protein S4 (SP:RS4_HUMAN) & 81.1 & 72.6 & 107 & 1 & BLASTX & 441 & $3.5 e-56$ \\
\hline SMPBD32R & W06723 & rho-GDP dissociation inhibitor (GP:MUSGDPDI_1) & 75.0 & 52.1 & 48 & 1 & BLASTX & 138 & $4.4 \mathrm{e}-19$ \\
\hline SMPBE16R & W06818 & Synaptophysin(PIR:A60548) & 60.5 & 39.5 & 43 & 1 & BLASTX & 87 & $9.3 e-08$ \\
\hline SMPBE57F & W06748 & Tubulin beta chain (PIR:S18457) & 98.1 & 94.4 & 107 & 1 & BLASTX & 543 & $6.8 \mathrm{e}-70$ \\
\hline SMPBF13F & W06770 & Polyubiquitin (X60390) & 99.0 & 99.0 & 105 & 2 & BLASTX & 517 & $6.1 \mathrm{e}-67$ \\
\hline SMPBF52R & W06824 & Vacuolar ATP synthase - subunit B(SP:VAT_DROME) & 97.0 & 94.0 & 68 & 1 & BLASTX & 335 & $1.4 \mathrm{e}-39$ \\
\hline SMPBE65R & W06819 & Yeast hypothetical 103.7KD Protein (SP:YBM7_YEAST) & Г) 74.1 & 51.9 & 27 & 1 & BLASTX & 71 & $4.4 \mathrm{e}-11$ \\
\hline
\end{tabular}




\section{DISCUSSION}

Tables IV and V show that some of the genes with homology either to $S$. mansoni or with other organism were sequenced more than twice. This is the case of GAPDH (11 times selected from the library), GST ( $9 \mathrm{X})$, frutose 1,6 biphosphate aldolase $(7 \mathrm{X})$, actin $(14 \mathrm{X})$ and $\mathrm{Y}$-box binding protein $(10 \mathrm{X})$ showing a certain degree of redundance of the library as had been previously reported (Franco et al. 1995a). Adams et al. (1995) defined some parameters to define whether a library has sufficient quality for the purpose of generating ESTs. These parameters include the proportions of: vectors without inserts, contaminant of the library with others cDNAs (host or bacteria), presence of mitochondrial DNA or rRNA, number of new genes, number of genes matching other organism genes and number of genes with homology to the original organism ( $S$. mansoni in our case). Although some redundancy was found, the library is still considered of very good quality, especially when we take in account the fact that $81 \%$ of the genes identified were new. Thus, we believe that it is worth pursuing further work with this library for the generation of new ESTs.

Among the new genes identified by homology with other organisms several stand out for having significant biological interest. Thus, an EST with homology to synaptophysin gene was found. In mammals, synaptophysin is one of the major integral membrane proteins of synaptic vesicles (McMahon et al. 1996) it is speculated that synaptophysin may function as a gap junction-like pore or channel (Calakos \& Scheller 1994). Another homology that called our attention is the one with a NIFS-like protein from yeast. The NIFS-like protein is supposed to be involved in both tRNA-processing and mitochondrial metabolism (Kolman \& Soll 1993), two interesting targets for design of new drugs.

The EST approach is also contributing for adding new members into gene families. Members of the family of GDP dissociation inhibitors (GDI) for the ras-related rho-subtype proteins appear to take part in the regulation of a number of biological processes, including cell growth and differentiation. We have identified an EST with a high similarity (75\%) with a murine D4 cDNA, a new member of the GDP-GDI family (Adra et al. 1993).

From these initial identifications, one cannot ascertain to the $S$. mansoni genes the same functions of those founds to the homologue genes in other organisms. However, these identifications open new avenues to further characterise these genes and through functional studies obtain a correlation between gene function and homology with the most diverse organisms. 
Through the sequencing of this adult cDNA library, a great number of new genes were identified in S. mansoni, showing the high efficiency of the EST approach. However, this parasite presents a complex life cycle with enormous changes in its morphology. Obviously, one would expect that such great changes are accompanied by changes at the gene expression level. Furthermore, if one considers the acquisition of information about the worm gene expression in the perspective of designing new drugs and/or vaccines, the young stages cannot be overlooked. Actually, the schistosomula stage is recognized as the main target to the host immune system attack (Smithers \& Terry 1965). With the foregoing in mind it is our future aim to study the expression pattern of the different life stages of S. mansoni by sequencing cDNA libraries for the distinct stages.

\section{ACKNOWLEDGEMENTS}

To Kátia Barroso for carrying out automated DNA sequencing.

\section{REFERENCES}

Adams MD, Kerlavage AR, Fleischmann RD, Fuldner RA, Bult CJ, Lee NH, Kirkness EF, Weinstock KG, Gocayne JD, White O, Sutton G, Blake JA, Brandon RC, Chiu MW, Clayton RA, Cline RT, Cotton MD, Earle-Hughes J, Fine LD, FitzGerald LM, FitzHugh WM, Fritchman JL, Geoghagen NSM, Glodek A, Gnehm CL, Hanna MC, Hedblom E, Hinkle Jr. PS, Kelley JC, Klimek KM, Kelley JC, Liu LI, Marmaros SM, Merrick JM, MorenoPalanques RF, McDonald LA, Nguyen DT, Pellegrino SM, Phillips CA, Ryder SE, Scott JL, Saudek DM, Shirley R, Small KV, Spriggs TA, Utterback TR, Weidman JF, Li Y, Barthlow R, Bednarik DP, Cao L, Cepeda MA, Coleman TA, Collins EJ, Dimke D,
Feng P, Ferrie E, Fischer C, Hastings GA, He WW, $\mathrm{Hu}$ JS, Huddleston KA, Greene JM, Gruber J, Hudson P, Kim A, Kozak DL, Kunsch C, Ji H, Li H, Meissner PS, Olsen H, Raymond L, Wei YF, Wing J, $\mathrm{Xu} \mathrm{C}$, Yu GL, Ruben SM, Dillon PJ, Fannon MR, Rosen CA, Haseltine WA, Fields C, Fraser CM, Venter CJ 1995. Initial assessment of human gene diversity and expression patterns based upon 83 million nucleotides of cDNA sequence. Nature 377 (Suppl). 3-174.

Adra CN, Leonard D, Wirth LJ, Cerione RA, Lim B 1993. Identification of a novel protein with GDP dissociation inhibitor activity for ras-like proteins CDC4Hs and rac I. Gens Chromosom Cancer 8: 253-261.

Calakos N, Scheller RH 1994. Vesicle-associated membrane protein and synaptophysin are associated on the synaptic vesicle. J Biol Chem 269: 24534-24537.

Franco GR, Adams MD, Soares MB, Simpson AJG, Venter JC, Pena SDJ 1995a. Identification of new Schistosoma mansoni genes by EST strategy using a directional cDNA library. Gene 152: 141-147.

Franco GR, Simpson AJG, Pena SDJ 1995b. Sequencing and identification of expressed Schistosoma mansoni genes by random selection of cDNA clones from a direction library. Mem Inst Oswaldo Cruz, 90: 215216.

Kolman C, Soll D 1993. SPL1-1, a Saccharomyces cerevisiae mutation affecting tRNA splicing. $J$ Bacteriol 175: 1433-1442.

McMahon HT, Bolshakov VY, Janz R, Hammer RE, Siegelbaum SA, Sudhof TC 1996. Synaptophysin, a major synaptic vesicle protein, is not essential for neurotransmitter release. Proc Natl Acad Sci USA 93: 4760-4764.

Smithers S, Terry RJ 1965 . The infection of laboratory hosts with cercarial of $S$. mansoni and the recovery of adult worms. Parasitology 55: 695-700. 